\title{
Community Surveillance Tanggap Darurat Pemerintah Daerah Penduduk Rentan Terkait COVID-19 di Kabupaten Klaten
}

\author{
Ratih Puspita Febrinasari ${ }^{1,3}$, Veronika Ika Budiastuti ${ }^{2,3}$, Nurholis Majid ${ }^{3}$, Anis \\ Nurhidayati $^{3}$, Ignatius Gonggo Prihatmono ${ }^{3}$, Irma Prasetyowati ${ }^{3}$, Ari \\ Probandari $^{3,4}$
}

1. Laboratorium Farmakologi, Fakultas Kedokteran Universitas Sebelas Maret

2. Laboratorium Biokimia, Fakultas Kedokteran Universitas Sebelas Maret

3. Program Studi S3 Kesehatan Masyarakat, Sekolah Pascasarjana, Universitas Sebelas Maret

4. Laboratorium Ilmu Kesehatan Masyarakat, Fakultas Kedokteran Universitas Sebelas Maret

\begin{abstract}
ABSTRAK
Pendahuluan: Awal tahun ini, dunia menghadapi pandemi Covid-19. Berawal dari Wuhan China, dan sampai di Indonesia. Dampak Covid-19 adalah kasus yang berat dan kematian. Di Indonesia, ada 57.000 kasus yang dikonfirmasi dan 2.934 meninggal. Lebih dari 82\% kasus kematian berusia lanjut. Dalam hal komorbiditas, sebagian besar kasus kematian memiliki hipertensi, diabetes melitus, gagal jantung dan gagal ginjal. Penelitian ini bertujuan untuk menilai respon untuk melawan Covid-19 melalui pengawasan masyarakat, terutama bagi penduduk yang rentan.

Metode: Metode yang digunakan yaitu wawancara secara online kepada 25 kepala keluarga sebagai data kuantitatif. Metode penilaian lainnya adalah kualitatif online di kalangan masyarakat, tokoh masyarakat, kepala keluarga, kader, dan pemerintah desa.

Hasil dan diskusi: Sebanyak 80\% responden setuju bahwa infeksi COVID-19 menyebar melalui droplet dan $84 \%$ kepala keluarga memahami gejalanya. Mereka memiliki pengetahuan yang baik tentang cuci tangan, memakai masker, menjaga jarak dan isolasi. Pengetahuan tentang pencegahan kelompok rentan sangat rendah. Hanya 32\% yang tahu bahwa lansia memiliki risiko kematian pada COVID-19. Kematian pada COVID-19 termasuk dikarenakan oleh hipertensi dan diabetes melitus. Terkait hasil kualitatif, hanya 2 dari 15 responden yang memahami jumlah penduduk rentan di daerahnya. Tidak ada kebijakan yang jelas terkait dengan penduduk rentan terutama di kabupaten. Tidak ada pengawasan masyarakat di antara penduduk yang rentan.

Kesimpulan: Pengawasan masyarakat terkait COVID-19 telah berlaku, tetapi penduduk rentan masih khawatir. Rekomendasinya yaitu mengembangkan model pengawasan masyarakat tentang perlindungan populasi yang rentan terhadap COVID-19.
\end{abstract}

Kata Kunci: Community Surveillance; Covid-19; Era Pandemi

\begin{abstract}
Introduction: Beginning of this year, the world faced the Covid-19 pandemic. Started from Wuhan, China went to other countries, including Indonesia. The impact of Covid-19 was severe case and mortality. In Indonesia, there were 57,000 confirmed cases and 2,934 died. More than 82\% of dead cases were elderly. In terms of comorbidity, most of the death cases had hypertension, diabetic mellitus, heart failure and renal failure. Then the question was how Indonesia handle this vulnerable population. This study aimed to assess the response to fight with the Covid-19 through community surveillance, especially for vulnerable population.

Methods: Method used for this study was online interviewed among 25 household leaders as quantitative data. Other assessment method was online qualitative among community, community leader, household leader, cadres, and village government. For additional methods, there was a policy analysis.

Results and disscussions: $80 \%$ of respondents agree that COVID-19 infection spreads through droplets and $84 \%$ of household leaders understand the symptoms. They had a good knowledge on handwashing, mask, social distance, and isolation. Knowledge on vulnerable prevention was very low. Only 32\% knew that elderly have dead risk on COVID-19. It was included the hypertension and Diabetic Mellitus.
\end{abstract}

Correspondence: Dr. Ratih P Febrinasari, dr, M.Sc., Laboratorium Farmakologi, Fakultas Kedokteran, Universitas Sebelas Maret; Program Studi S3 Kesehatan Masyarakat, Sekolah Pascasarjana, Universitas Sebelas Maret, ratihpuspita@staff.uns.ac.id 
Related to qualitative results, only 2 out of 15 respondences understood the number of vulnerable populations in their area. There was no clear policy related the vulnerable population especially in district and below on vulnerable protection. There was no community surveillance among vulnerable population.

Conclusions: Community surveillance related to COVID-19 has in place in the community level, but concerns among vulnerable population was still low. Recommend to develop a community surveillance model on vulnerable population protection against COVID-19.

Keywords: Community Surveillance; Covid-19; Pandemic Era

\section{PENDAHULUAN}

Indonesia merupakan salah satu dari 213 negara yang juga terkena pandemi virus covid19. Untuk mengendalikan pandemi yang semakin menyebar dan meluas, diperlukan kerjasama semua pihak dan elemen bangsa. Setiap hari telah terjadi peningkatan kasus dan kematian oleh Covid-19 dimana tingkat kematian Covid-19 adalah 4-8\%. Pemerintah Daerah khususnya Provinsi Jawa Tengah sudah menyampaikan bahwa status tanggap darurat bencana SARS Covid-19 ini ditetapkan dengan SK Gubernur Jawa Tengah Nomor 360/3/Tahun 2020 tentang Penetapan Status Tanggap Darurat Bencana Corona Virus Disease di daerah Jawa Tengah, dari tanggal 27 Maret 2020. Pemkab Klaten juga melakukan penetapan bahwa status Kejadian Luar Biasa (KLB), saat seorang warga Klaten terkonfirmasi mengidap positif Covid-19 dan sedang menjalani perawatan serta pengobatan isolasi di RSD Bagas Waras Klaten ${ }^{4}$.

Pengendalian Covid-19 perlu dilakukan dengan cermat dan dukungan data yang adekuat. Data pengetahuan, sikap dan perilaku dari masyarakat, kader, ketua RT dan tenaga kesehatan serta kebijakan pendukung akan membantu kelancaran pengendalian Covid-19 ini. Pengendalian Covid-19 adalah sebuah upaya dalam mencegah tersebarluasnya dan menurunkan kasus dan kematian akibat Covid-19 di masyarakat. Dalam rangka pengendalian penyakit Covid-19 ini, dibutuhkan langkah yang tepat dan cermat berbasis data. Data pengetahuan, sikap dan perilaku semua elemen di masyarakat sangat diperlukan untuk memberikan rekomendasi dan langkah yang tepat dalam pengendalian Covid-19. Terdapat beberapa kesenjangan informasi pengetahuan, sikap dan perilaku antar elemen sehingga terjadi hambatan dalam pengendalian Covid-19. Tujuan kegiatan ini adalah mendapatkan gambaran analisis kebijakan pemerintah daerah Kabupaten Klaten dalam melaksanakan penanggulangan Covid-19 pada penduduk rentan.

\section{METODE}

Rancangan penelitian adalah cross sectional dengan pendekatan mixed method yaitu dengan melakukan penelitian kualitatif dan kuantitatif. Penelitian dengan kualitatif ini dilakukan dengan studi kasus terhadap penanganan Covid-19, sedangkan penelitian kuantitatif berupa analisis tingkat pemahaman pemerintah daerah dalam menangani Covid-19. Penelitian ini dilaksanakan di Kabupaten Klaten dengan waktu penelitian dimulai April 2020 sampai Juni 2020.

Variabel penelitian adalah kebijakan dan regulasi Covid-19, tingkat pengetahuan dan pemahaman aparat pemerintah dalam penanganan Covid-19 pada penduduk rentan. Metode pengumpulan data yang digunakan menggunakan pengumpulan kuesioner dengan bantuan media online. Sasaran penelitian adalah ketua RT, sedangkan untuk tahap kualitatif sasarannya 
adalah ketua RT, satgas Covid RW, kader kesehatan, dan tokoh masyarakat. Teknik analisis data dan keterangan ethical clearance.

\section{HASIL DAN PEMBAHASAN}

Penelitian ini melibatkan 25 ketua RT untuk responden kuantitatif, 15 responden kualitatif.

Tabel 1. Karakteristik Responden

\begin{tabular}{lc}
\hline \multicolumn{1}{c}{ Karakteristik } & \% atau Rerata (Min-Maks) \\
\hline Umur dalam tahun & $48(30-67)$ \\
Lama Jadi ketua RT & $7(1-19)$ \\
Pendidikan & \\
Pendidikan Rendah & $34 \%$ \\
Pendidkan Tinggi & $66 \%$ \\
Pekerjaan & \\
Pegawai Pemerintah & $8 \%$ \\
(ASN) & \\
Pegawai Swasta & $36 \%$ \\
Pekerja Informal & $36 \%$ \\
Wiraswasta & $20 \%$ \\
\hline
\end{tabular}

Tabel 1 ini memperlihatkan bahwa rata-rata usia responden adalah 48 tahun dengan lama menjadi ketua RT 7 tahun. Mayoritas responden berpendidikan tinggi (66\%) dan memiliki pekerjaan sebagai pegawai swasta dan buruh (36\%).

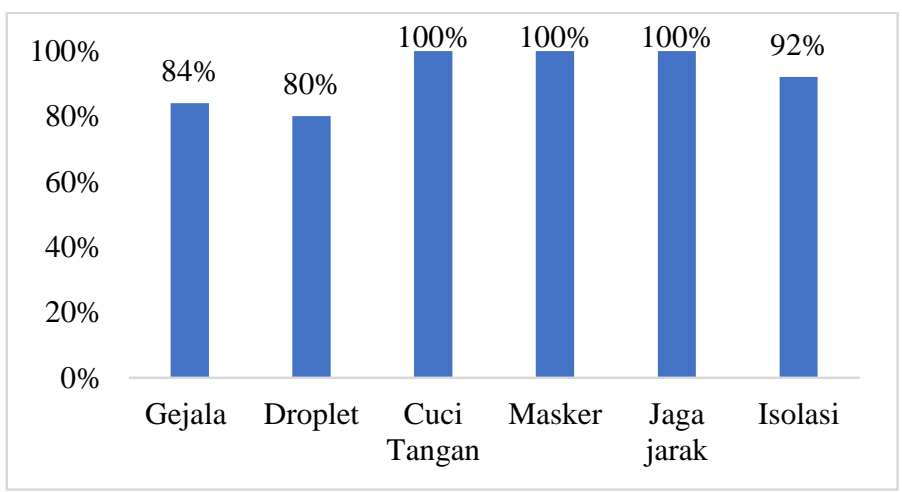

Gambar 1. Pengetahuan Ketua RT tentang Covid 19

Gambar 1 menunjukkan bahwa dari 25 ketua RT yang diwawancara secara online, didapatkan 84\% mengetahui gejala Covid-19, 80\% mengetahui penularan Covid-19 melalui peesikan ludah/droplet. Pengetahuan dalam aspek pencegahan, semua ketua RT mengetahui cuci tangan, penggunaan masker dan jaga jarak merupakan pencegahan Covid-19. Terdapat 92\% yang meyakini bahwa isolasi mandiri juga bagian dari pencegahan Covid-19. 


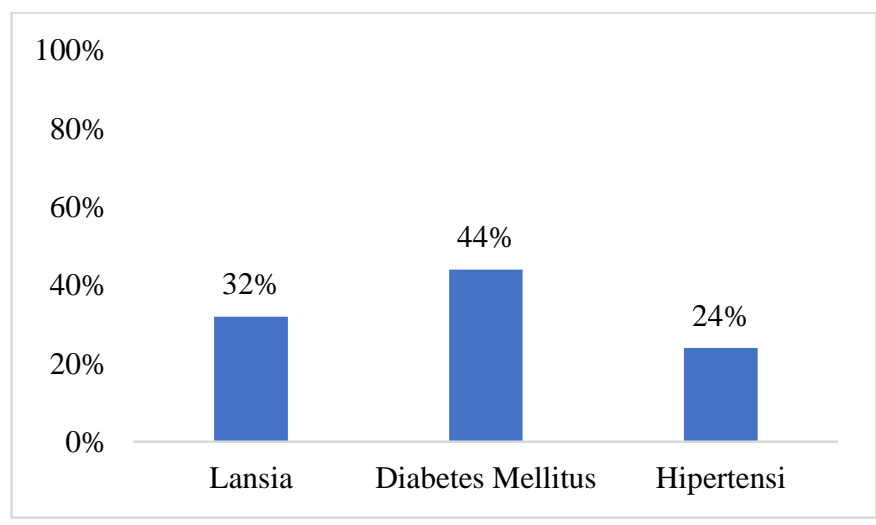

Gambar 2. Pengetahuan ketua RT tentang Perlu Isolasi Bagi Penduduk Rentan

Gambar 2 menunjukkan bahwa dari 25 ketua RT yang diwawancara secara online, didapatkan 32\% mengetahui lansia merupakan penduduk rentan yang perlu dilakukan isolasi, $44 \%$ mengetahui warga dengan penyakit kencing manis merupakan penduduk rentan yang perlu dilakukan isolasi dan $24 \%$ mengetahui warga dengan penyakit hipertensi merupakan penduduk rentan yang perlu dilakukan isolasi.

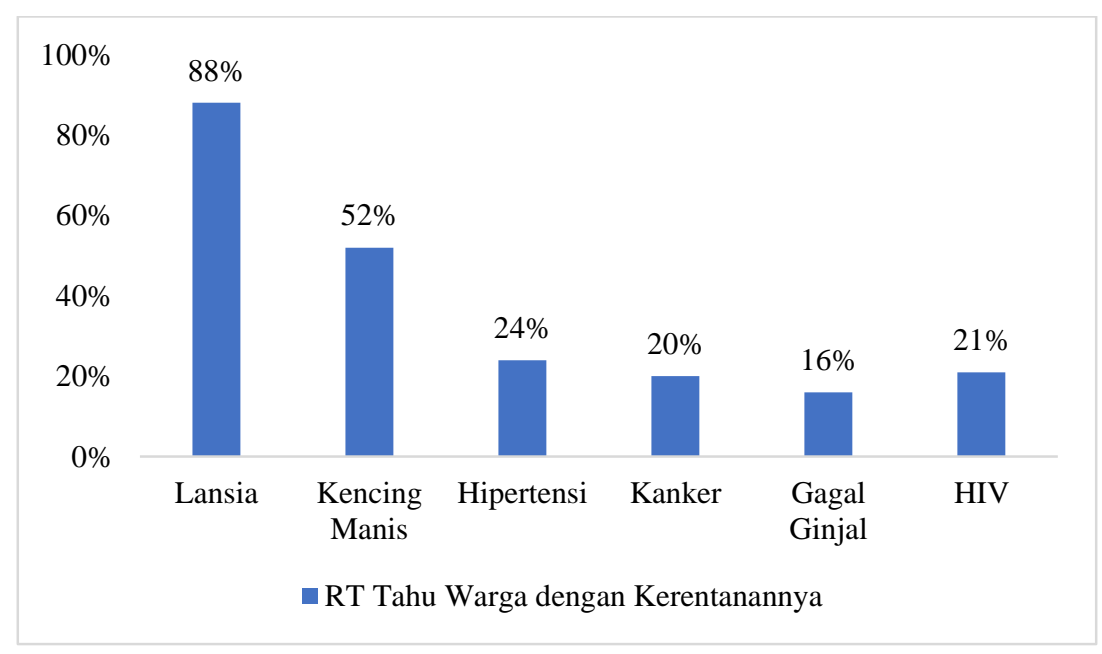

Gambar 3. Pengetahuan Ketua RT tentang Jumlah Warga dengan Kerentanan

Gambar 3 menunjukkan bahwa 88\% ketua RT mengetahui jumlah warga lansia, 52\% warga yang menderita kencing manis, $24 \%$ warga yang menderita hipertensi, $20 \%$ warga yang menderita kanker, $16 \%$ warga yang menderita gagal ginjal dan $21 \%$ warga yang menderita HIV.

Produk Kebijakan di Kabupaten Klaten dimulai di level kabupaten, kecamatan, desa sampai Rukun Warga (RW). Berikut beberapa gambar kebijakan yang ada di Kabupaten Klaten pada Gambar 4. 

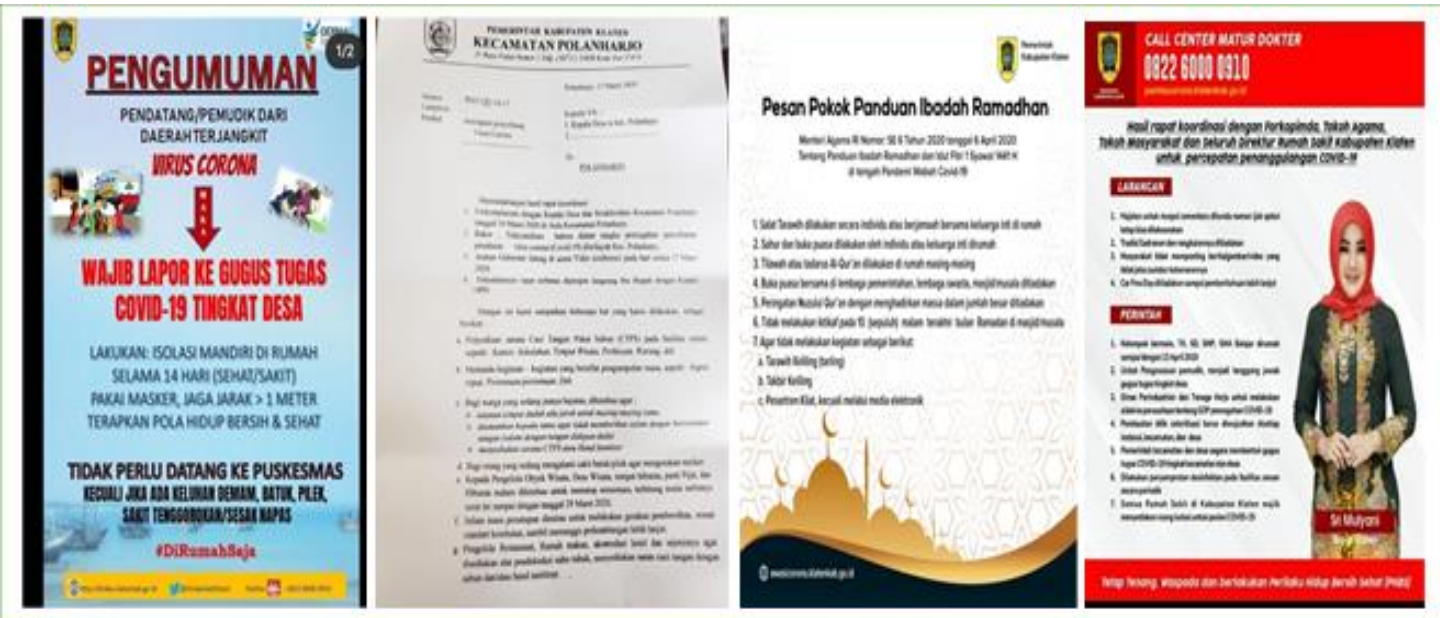

Gambar 4. Produk kebijakan Penanggulangan Covid 19 di Kabupaten Klaten

Analisis kebijakan dengan menggunakan tiga pilar dari Buse et.al, 2005, di mana terdiri dari konteks, proses dan isi dengan mempertimbangkan pelaku dalam pembuaatan kebijakan dan pelaksana kebijakan. Aspek konteks melihat kebijakan berdasarkan situasi masyarakat dan kemampuan layanan kesehatan ${ }^{1}$.

Aspek konteks kebijakan pemerintah daerah Kabupaten Klaten dalam penanggulangan Covid-19 pada penduduk rentan sesuai dengan struktur demografi penduduk yakni rasio ketergantungan sebesar 49\% (11\% lansia). Hal ini perlu dipertimbangkan karena kasus terburuk kebanyakan pada umur lansia ${ }^{2}$. Hasil observasi surat edaran/kebijakan/himbauan yang diberikan pemerintah Kabupaten Klaten dalam mewujudkan kebijakan tanggap darurat penanggulangan Pandemi Covid-19 dalam berbagai aspek namun belum tergambarkan kebijakan yang bersifat khusus pada penduduk rentan yakni: balita, lansia, dan penduduk dengan penyakit kronis penyerta.

Aspek proses penyusunan kebijakan, dilakukan sejak identifikasi masalah, perumusan kebijakan, pelaksanaan kebijakan dan evaluasi kebijakan ${ }^{1}$. Proses penyusunan kebijakan untuk percepatan penanggulangan Covid-19 telah dilakukan dengan melibatkan lintas sektor melalui Rapat Koordinasi Pimpinan Daerah (Rakor Forpimda), tokoh agama, tokoh masyarakat dan seluruh Direktur Rumah Sakit di wilayah Kabupaten Klaten sebagai Aktor Perumusan kebijakan pemerintah daerah Kabupaten Klaten dalam percepatan penanggulangan Covid-19 telah memperhatikan berbagai aspek dan melibatkan peran lintas sektor. Kerjasama unsur eksekutif dan legistatif teridentifikasi dalam persetujuan perubahan Anggaran Pendapatan Belanja Daerah (APBD) dalam merespon upaya percepatan penanggulangan Covid-19.

Aspek isi, berdasarkan setiap sektor yang terlibat dengan penduduk rentan. Sektor kesehatan terdapat penerapan PHBS, penyemprotan desinfektan, pemakaian masker, pembatasan sosial dan fisik, pelaksanaan karantina mandiri, penanganan DBD, pengadaan Alat Pelindung Diri dan ruang isolasi penderita Covid-19 di semua rumah sakit, pemanfatan fasilitas kesehatan terdekat sebagai rujukan terdekat dan pemanfaatan call center "matur Dokter". Penyediaan untuk melakukan cuci tangan memakai sabun dan air mengalir atau sanitizer di tempat tempat umum. Tetapi tidak ada kebijakan spesifik terkait penduduk rentan. Terkait dengan aspek pendidikan, belajar di rumah pada semua pendidikan yaitu mulai dari SD sampai dengan SMA/SMK. Aspek ketenagakerjaan, dalam hal ini dibentuk tim yang melakukan inspeksi mendadak (sidak) ke perusahaan-perusahaan terkait. Tim ini yang akan memastikan 
bahwa setiap perusahaan di Klaten telah mematuhi Standard Operating Procedure (SOP) sebagai upaya pencegahan corona.

Aspek sosial ekonomi, pengadaan lumbung pangan di tingkat desa, dengan melakukan bantuan berupa sembako (Sembilan Bahan Pokok) bagi warga yang terkena dampak Covid-19, menunda kegiatan rapat dan pertemuan, melarang kegiatan sadranan dan menunda hajatan dan cara pemulasaraan jenazah dan larangan penolakan penguburan jenazah pasien Covid-19. Sektor pariwisata, penutupan sementara objek pariwisata, desa wisata, tempat hiburan, panti pijat, hiburan malam sampai menunggu perkembangan selanjutnya. Pembersihan daerah wisata selama penutupan sementara dan pengelola hotel, rumah makan wajib menyediakan alat deteksi suhu tubuh, menyediakan sarana tempat mencuci tangan memakai sabun dan juga air mengalir.

Sektor keagamaan, penundaan kegiatan keagamaan di tempat umum dan melakukan kegiatan ibadah keagamaan di rumah serta pengaturan pengelolaan zakat fitrah. Sektor keamanan dan ketertiban, Peningkatan kewaspadaan terhadap keamanan lingkungan sekitar, meningkatkan fungsi sistem keamanan lingkungan dengan berkoordinasi dengan aparat kemanan dan ketertiban

Covid-19 sudah menyebar ke seluruh dunia dan menjadi pandemi. Ketepatan dalam pengelolaan menurunkan kecepatan dalam penambahan kasus dan mengurangi kematian termasuk di Indonesia. Di Indonesia terdapat 52.275 kasus terkonfirmasi dengan kematian sebesar 248 kasus $^{3}$. Klaten merupakan salah satu kabupaten dengan tingkat kasus yang terus meningkat tetapi belum ada kematian. Peningkatan kasus ini, berdampak pada peningkatan kasus kematian apabila tidak ditangani dengan baik ${ }^{4}$.

Berdasarkan hasil laporan nasional Satgas Covid-19 Nasional maupun Jawa Tengah didapatkan bahwa angka kematian tertinggi terjadi pada kelompok umur di atas 65 tahun sebesar 38\%, hipertensi, kencing manis dan penyakit kronis lainnya. Ini sesuai dengan laporan dari China dan Amerika dengan odds ratio(OR) sebesar 2.534.

Pemerintah sudah mendorong melakukan organisasi secara masif dari tingkat nasional sampai dengan tingkat RW. Pelibatan masyarakat, pemerintah daerah dan sektor kesehatan merupakan tantangan tersendiri dan merupakan bagian dari penggerakan survailans komunitas. Tugas dari tiap satgas Covid-19 adalah meningkatkan pendidikan masyarakat, memantau setiap kecurigaan kasus dan kasus, meningkatkan perilaku masyarakat yang sesuai protokol kesehatan.

Masyarakat juga mempunyai pengetahuan tentang gejala yang cukup tinggi. Hasil ini hampir sama dengan laporan yang disampaikan oleh China, dan beberapa negara lainnya. Penelitian yang dilakukan oleh Clements, $2020^{8}$. menunjukkan sebagian besar orang di Amerika Serikat mempunyai pengetahuan dan perilaku yang baik. Zhong (2020) yang melakukan penelitian terhadap mereka yang ada di wilayah China yang dimana sebagai tempat pertama kali ditemukan virus yang menyebabkan pandemi ini juga mendapatkan pengetahuan dan juga perilaku yang baik serta positif ${ }^{9}$. Artinya dorongan informasi dari nasional ke lapangan cukup efektif.

Pengetahuan masyarakat terkait dengan pandemi Covid-19 ini adalah hal yang menjadi sangat penting di masa pandemi seperti ini, hal ini yang meliputi penyebabnya dan karakteristik dari virus Covid-19, tanda dan gejala. Selain itu, istilah yang terkait dengan covid-19, pemeriksaan yang perlu untuk dilakukan dan proses transmisi serta upaya pencegahan penyakit yang diakibatkan virus ini. Tingkat pengetahuan yang baik dapat didukung oleh penerimaan terhadap informasi yang beredar dimasyarakat tentang Covid-19 ${ }^{10}$.

Perilaku cuci tangan, penggunaan masker, isolasi mandiri juga menjadi hal yang sangat diperhatikan oleh masyarakat. Ini hampir sama dengan survei yang dilakukan oleh BPS di mana 
kepercayaan masyarakat terkait masker sebesar $92 \%$, cuci tangan $90 \%$ dan jaga jarak $89 \%{ }^{11}$, Di Inggris $86 \%$ dan Amerika $93 \%$ yang percaya menggunakan masker, mencuci tangan dan juga jaga jarak dapat mencegah Covid-1912.

Untuk mencegah kematian tersebut, perlu dilakukan pemantauan secara khusus pada populasi rentan. Dari hasil asesmen, pemantauan hanya terjadi pada kelompok lansia, sedangkan pasien dengan komorbiditas belum mendapatkan perhatian. Amerika dan Australia telah melakukan pengawasan secara langsung dan mengembangkan telemedicine untuk kelompok terdampak ${ }^{13,14}$.

Dari sisi peraturan, dilakukan analisis dan didapatkan peraturan yang mendukung surveilans komunitas pada kelompok masyarakat rentan belum ada. Kondisi ini, perlu segera mendapatkan kebijakan pemerintah untuk segera mendorong pengembangan peraturan surveilans komunitas yang melibatkan banyak pihak. India dan Bangladesh juga menerapkan surveilans masyarakat dalam menghadapi Covid-19 ini $^{15}$.

\section{KESIMPULAN}

Surveilans komunitas untuk mendukung pencegahan covid secara keseluruhan sudah berjalan dengan baik, tetapi dukungan terhadap kelompok masyarakat rentan belum berjalan dengan baik. Untuk itu, direkomendasikan mendorong pengembangan surveilans komunitas terkait dengan masyarakat rentan dan didiseminaskan sampai dengan tingkat terbawah.

\section{DAFTAR PUSTAKA}

1. Buse K, Mays N, Walt G, Editors S, Black N, Raine R. Making Health Policy [Internet]. 2nd ed. Nick Black, Raine R, editors. London, UK: Open University Press; 2005. 213 p. Available from: www.openup.co.uk\%0Aand

2. Tian W, Jiang W, Yao J, Christopher ;, Nicholson J, Li RH, et al. Predictors of mortality in hospitalized COVID-19 patients: A systematic review and meta-analysis Running Head: Predictors of mortality in hospitalized COVID-19 patients. J Med Virol.

3. COVID-19 STP. Peta Sebaran [Internet]. Available from: https://covid19.go.id/petasebaran

4. COVID-19 STP. Analisis Data COVID-19 Indonesia Update per 30 Agustus 2020 [Internet]. [cited 2020 Oct 23]. Available from: https://covid19.go.id/storage/app/media/Analisis Data COVID-19 Indonesia/Analisis Data COVID-19 Mingguan Satuan Tugas per 30 Agustus 2020.pdf

5. Geldsetzer P. Use of Rapid Online Surveys to Assess People's Perceptions During Infectious Disease Outbreaks: A Cross-sectional Survey on COVID-19. J Med Internet Res. 2020 Apr;22(4):e18790.

6. Shereen MA, Khan S, Kazmi A, Bashir N, Siddique R. COVID-19 infection: Origin, transmission, and characteristics of human coronaviruses. J Adv Res [Internet]. 2020 [cited 2020 Oct 23];24:91-8. Available from: https://doi.org/10.1016/j.jare.2020.03.005

7. Wei WE, Li Z, Chiew CJ, Yong SE, Toh MP, Lee VJ. Morbidity and Mortality Weekly Report Presymptomatic Transmission of SARS-CoV-2-Singapore [Internet]. 2020 [cited 2020 Oct 23]. Available from: https://www.cdc.gov/mmwr

8. Clements JM. Knowledge and behaviors toward COVID-19 among us residents during the early days of the pandemic: Cross-sectional online questionnaire. J Med Internet Res [Internet]. 2020 May 1 [cited 2020 Oct 23];22(5). Available from: 
/pmc/articles/PMC7212816/?report=abstract

9. Zhong BL, Luo W, Li HM, Zhang QQ, Liu XG, Li WT, et al. Knowledge, attitudes, and practices towards COVID-19 among chinese residents during the rapid rise period of the COVID-19 outbreak: A quick online cross-sectional survey. Int $J$ Biol Sci. 2020;16(10):1745-52.

10. Sulistyaningtyas Tri. Informasi Wabah Virus Covid-19: Kuasa Pengetahuan dan Kelas Sosial. 2020; Available from: https://sinta.ristekbrin.go.id/covid/penelitian/detail/80

11. Badan Pusat Statistik. Hasil Survei Perilaku Masyarakat di Masa Pandemi COVID-19. Vol. 19. 2020.

12. Geldsetzer P. Knowledge and Perceptions of COVID-19 Among the General Public in the United States and the United Kingdom: A Cross-sectional Online Survey. Ann Intern Med [Internet]. 2020;(PG-). Available from: NS -

13. Centers for Disease Control and Prevention (CDC). Older Adults [Internet]. Available from: https://www.cdc.gov/coronavirus/2019-ncov/need-extra-precautions/olderadults.html

14. Departement of Health AG. Coronavirus (COVID-19) advice for older people [Internet]. 2020. Available from: https://www.health.gov.au/news/health-alerts/novelcoronavirus-2019-ncov-health-alert/advice-for-people-at-risk-of-coronavirus-Covid19/coronavirus-Covid-19-advice-for-older-people

15. Tripathi SC, Deshmukh V, Patil A, Tripathy JP. COVID 19 diagnostic multiplicity and its role in community surveillance and control. Le Infez Med. 2020 Jun;28(suppl 1):1828 